\section{A Fair Hearing for Behe}

\section{S. Joshua Swamidass (D)}

https://doi.org/10.54739/qc9a

D arwin Devolves is the new book from Micheal Behe, one of the leaders of the Intelligent Design movement. Nathan Lents, Richard Lenski, and I reviewed it in Science, in a brief article titled " The End of Evolution?" It was a negative review. This review was met with acrimony from Behe and his supporters at the Discovery Institute (DI).

Some wonder how a negative review of this book fits in with "Peaceful" Science. The peace we are seeking at Peaceful Science is not cheap or easy. The difficult peace we seek is unthreatened by disagreement, but it costs us the discomfort of honesty. The reconciliation we seek is subverted by silence. The way we are to seek peace and reconciliation, in fact, may increase conflict in the short term.

This review includes our honest and rigorous assessment: Behe fails to challenge evolutionary science because his book "misrepresents theory and avoids evidence that challenges him." With only 750 words, our review was a high level overview of problems we found with the book. It is a "table of contents," not a detailed explanation of our reasoning. Lents and I offered Behe and the DI opportunity to clarify any confusion they had about the review. They did not take our offer. Instead, there was a flurry of over 15 largely negative responses from the DI and Behe himself. Working together, we responded many of their responses as well as other flaws we perceive in Behe's book (directory here, main response here). The DI is well known for its colorful theatrics, especially when they are threatened. The flurry attracts attention to Behe's work, and will likely sell more of his books. Theatrics like this, however, undermine DI's quest to be taken seriously by scientists.

For those knee deep in the origins conversation, nonetheless, the exchange has been entertaining. I particularly enjoyed Behe's first response to us, "Who hoo!" He wrote that our review did not engage his hypothesis. This is one of Behe's standard responses, reflexly claiming that the critics do not understand him. I smiled when I read it, "classic Behe!" Lest there be any doubt, his hypothesis is quoted here with emphasis added,

...beneficial degradative mutations will rapidly, relentlessly, unavoidably, outcompete beneficial constructive mutations at every time and population scale.

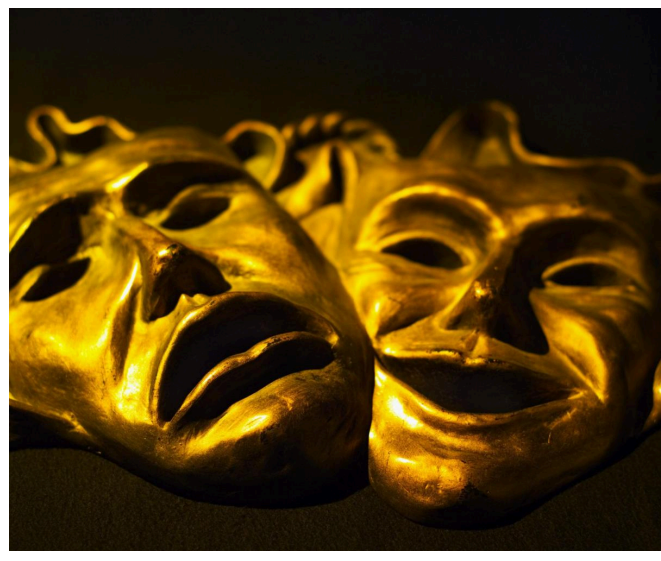

Our review did address this hypothesis. This characterization by Dennis Venema is spot on,

Author: erosion is really, really common. We see it all over the place. Here are hundreds of known examples. Mountains can't be natural.

Reviewer: the author doesn't address what we know about all the many, many geological processes that cause rock uplift.

Author: the reviewers don't even address my main argument!

\section{Dennis Venema}

This reading of the exchange is readily apparent to most observers. For example, the atheist biologist Jerry Coyne writes,

Behe appears to have missed the fact that the reviewers did address Behe's main point-at least twice."

Of course, from the get go, Lents and I reminded DI that the Science review as merely a high level overview. This misfire from Behe was unnecessary, but at least it was entertaining.

Darwin Devolves becomes publicly available today. Now everyone can read it. Soon, the conversation will grow. Many more reviews of his book will be published (for example this), and most of them-those by scientist-will not be kind. There is more to come from us too. Several articles are in the works by my co-authors and I. On February 28th, I am dialoguing with Ann Gauger, one of Behe's colleagues, in a taped dialogue in northern California. On March 16th, Jonathan McLatchie is live-streaming a conversation with me on his apologetics podcast. The conversation is just now beginning.

\section{Disagreement and Agreement}

I want a better way forward. In the current conversation, it is worth remembering that the salient disagreement is exceedingly narrow. As I have written before, " Thankfully, the salient disagreement is merely about the limits of modern science, not the reality of God's action in origins." In this case, our disagreement is merely about the validity of Behe's claims in Darwin Devolves, and not about whether or not God ever guided evolution. To help us along, I recently articulated and emphasized my substantial agreement with Behe on most things: 
1. We both reject Darwinism. I am not a Darwinist, and neither is Behe. Of course, I reject Darwinism for different reasons than Behe, and reject Darwinism without abandoning evolutionary science (see my explanation elsewhere).

2. We both affirm common descent, including the common descent of man with the great apes. I was brought to this conclusion, partly, by Behe himself.

3. We both agree that God created us, and in this sense He designed us all by a process of common descent. Neither of us deny God's action in our origins.

4. We both are willing to disagree with our peers in science, and I continue to admire Behe for his willingness to do so.

The key point: I am not ideologically opposed to Behe, nor am I biased against him or his conclusions. In fact, I actually agree with him on his ultimate conclusions. God created all things, and in this sense he designed us all.

Both before and after the Science review, I reached out to Behe and DI privately, hoping for a better way. They were wary and distrustful of me. I understand their concern. They really want Darwin Devolves to be correct. They are understandably disappointed by our negative Science review, even though it was less negative than the last Science review of Behe's work. I, however, was ethically bound to give an honest and professional review of Behe's book. Understandably, a negative review was not what they wanted, but it was an honest review.

For better or worse, I agree with Behe on most things, but I cannot agree that $1+1=3$; in fact, I feel obligated to say publicly that this is not true. This is not to suggest that Behe's oversights, as I see them, are easy to pick out and see. To many observers, most of the scientific details are technobabble, largely unintelligible. What looks like 1+1=3 to computational biologist me, appears esoteric and debatable to others. For me, with my training and knowledge, however, Behe's argument very much looks like $1+1=3$. Perhaps I am wrong. I am willing to explain and I am open to being convinced. This is not an appeal to authority; I am not saying this is why people should agree with me. I am willing to explain in detail my objections, and I have. My assessment is that it seems to me that Behe is arguing $1+1=3$; this is just where things stand right now.

\section{Theatre and Reality}

I am giving Intelligent Design a fair hearing. I am giving Behe a fair hearing. Scientists often tell me that attempting to give DI a fair hearing is a waste of time, a quixotic dream. I, nonetheless, believe dialogue is important, and that it can lead to real progress in our understanding. This is one of the ways Peaceful Science excelled over the last several years. As far as I know, we are the only group aligned with mainstream science that is hearing ID proponents out. Ironically, for this reason, it is no surprise the DI has directed many of their accusations specifically at me. It would be easier for them if I was biased against them, and unfair. I am not, so I am not not so easily dismissed.

On the one hand, I am inclined to ignore these accusations as their standard theatrics. DI often paints scientists as biased and unfair, in order to discredit our legitimate objections. I am not so easily dismissed: (1) I am a Christian, not an atheist, (2) I am not a
Darwinist, (3) I am an accomplished scientist, and (4) I have a long track record of being fair to and including them. With this in mind, the narrative DI and Behe are putting out about me is not true, but it sure makes for a great show! Very entertaining.

On the other hand, the noise from DI grows louder, and out of context quotes abound. I am a difficult critic for them right now. It is no surprise that DI has been very intent on discrediting me this time around. Many observers do not know our history, and they don't know the DI theatre is a theatre; they may need some help making sense of this. There are several objective facts I want to bring forward to demonstrate that the current narrative from DI is not reality. This list is not comprehensive. Many details are left out, in order to protect friends of mine within the Intelligent Design movement from retribution.

1. Just a few months ago, the DI and I found common ground in a (friendly) disagreement with Nathan Lents. I agree with DI that the so called "bad design" argument is a bad argument against intelligent design. These "bad design" arguments are better understood as evidence of common descent, and research questions for further inquiry.

2. Very recently, both secular scientists and I were defending work done by the DI on population genetics. We see how to extend this work and make it more rigorous, and invited (and continue to invite) the DI to collaborate with us to answer these big questions about human origins.

3. I am convincible. In the past, ID advocates have changed my mind. Most famously, they changed my mind about the genetic evidence against an ancient bottleneck more ancient than 500,000 years ago.

4. On the forum, dialogue with Dr. Brian Miller (From DI) on Doug Axe's work has continued during this time. Dr John Mercer and other scientists have brought forward several important findings and studies that directly contradict Axe's extrapolations on protein structure and function. These findings demonstrate, it appears, that an irreducibly complex beta -lactamase enzyme appears in a library of less than $10^{10}$ random sequences.

5. I assembled several scientists to discuss with Winston Ewert (from DI) his work on the Dependency Graph of Life. This dialogue ended with a positive review of his work, though he has much to do to make his case. We look forward to his return.

6. This last month, I organized two workshops on the Genealogical Adam and Eve, paying travel and lodging for two leaders from the DI to join us. My guests included Walter Bradley, one of the founders of the ID movement, who communicates his deep appreciation of our work. I hope he will endorse my forthcoming book. A workshop I ran this summer on the Science of Adam, also included these two ID leaders.

I could go on with many more examples. The point, however, is that the narrative coming out of DI about me is not reality. The conflict is public theatre. It will pass. Reality is much more inspiring. Peaceful Science is finding a new way forward.

I am actively including DI, inviting their scholars to join us. I can give them a fair hearing. I will. As they come to the table, however, they will face honest critique from scientists when we disagree. In the end, they may fail to make their case. Or, at times, they might show us 
something new. With Behe's book negatively reviewed by me, this is a hard trade off for them right now, but a fair hearing is the best anyone can do for them. This is how science works. In this way, too, the peace we seek is not an easy peace. It brings real disagreements to the surface, so that dissenting views might get their fair hearing.

\section{A Better Conversation Arising}

I am encouraged that sensible dialogue is now arising, the dialogue our Science review was intended to encourage. Behe believes our assessment is incorrect. I expect the public dialogue on his ideas will make clear where things stand. In particular, I want to highlight two articles by my co-author, Richard Lenski, and one by Joel Duff.

1. Lenski begins a three part series, detailing and explaining why most scientists are not going to be convinced by Behe's book.

2. Expanding on Nathan Lent's and Arthur Hunt's points, Lenski also comments on whether or not polar bears evolved by destructive evolution or not. This example was chosen by Behe as an icon of his Devolution thesis, and appears in the publicly available first chapter of the book.

3. The surprising rise of polar pears in this conversation is delightful. I direct readers to Joel Duff's diagnostic on origins views, guides readers through multiple proposals for how polar bears got here.

A graduate student commented that Lenski is an uncommonly lucid writer. He wants to see Lenski write a book for the general public. I agree. This series will be excellent. It is exactly the work to which our review in Science is meant to draw attention.

Going forward, I want to emphasize, especially to religious readers, that Lenski is not an anti-religious Darwinist. $\mathrm{He}$ is an excellent scientist, seeking the good of society, and giving a truthful account of what he sees. Lenski is private about his religious views, but his oddly named blog is a clue. "Telliamed" is a reference to an old book about

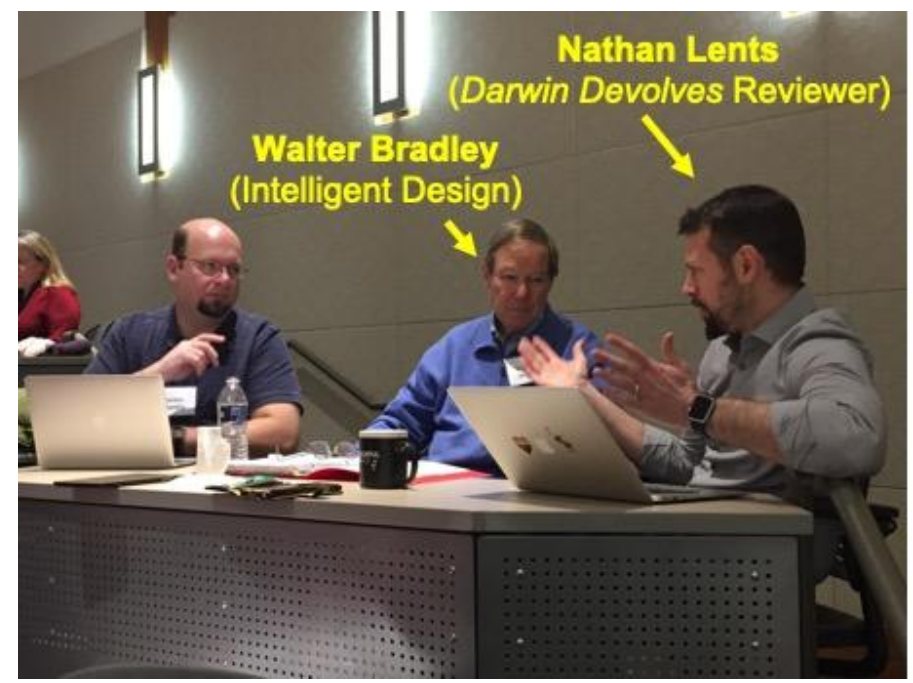

This photo from last month shows the reality of Peaceful Science\&rsquo;s relationship with DI. Nathan Lents, my coauthor, discusses science and theology with Walter Bradley, one of the founders of Intelligent Design. They were both guests at the January workshop on the Genealogical Adam and Eve. There were scholars from across the whole spectrum engaging the grand questions together. There was no acrimony. This is the reality, and it is more inspiring than the theatre. a fictional conversation between an Indian Philosopher and a French Missionary, a conversation that resembles the conversation between science and theology in present day. Lenski, also, explained to Behe that he is concerned by the model of interaction between religion and science being put forward by the Intelligent Design movement. Most of the scientific community echoes these concerns. We need a better way forward.

\section{Thinking About Behe's Rule}

Despite some appearances, quite a bit of progress has been made right now. I want to summarize a few points.

1. There has been several complaints that we made mistakes or misrepresented Behe. Do not mistake our assessment (with which Behe certainly disagrees) with our representation of his arguments. There are several remaining objections from DI that seem to be the result of DI misreading our review. For those interested in the details, please read my response to Behe's comment on our Science review.

2. Polar bears are put forward by Behe as an icon of his thesis. Behe clarified the reasoning by which he concludes that the adaptive genes in polar bears are mainly damaged. I'm concerned, however, that Behe called Nathan Lents and Arthur Hunt "incompetent" for pointing out what looks to be an error. There will be much more written about why most scientists disagree with his reasoning. I look forward to Behe's promised response to Lensky, Lents, and Hunt.

3. An unsigned post from DI answers Arthur Hunt and me on several long-standing objections to the Edge of Evolution, Behe's prior book that his current book relies upon. To Behe's credit, this post appears to concede several major points. Our surprise is muted because Behe himself was not credited for this article. To move forward, we request that Behe publicly state he agrees with this article in entirety, or write an article of his own. There has been a reoccurring pattern of well-meaning DI supporters misrepresenting Behe's work. We want to avoid a misfire by hearing directly from Behe on this point.

4. In a different direction, Behe hypothesizes that within family evolution can be explained without appealing to "infusions of information." What about the origins of humans from common ancestors with the great apes? Chimpanzees, apes, orangutans, and humans are all the same family, less different than mice and rats. If "infusions of information" are required for human origins, on what basis does he determine this? No trap here, but I wonder what his hypothesis means for the elephant in the room: human origins.

May the conversation continue. There is virtue in the wasteland of the origin wars. It is the acrimony that sets the conditions for true virtue to arise and be recognized. Do not be afraid. Worry not about the conflict; this too shall pass.

\section{Polar Bears Hunt}

The science we are discussing is bringing us into the beauty of nature. We can't resist explaining it more. Right now I am dreaming of polar bears. They are the largest land predators on earth, specialized to live on ice and hunt seals. 
Come gather around. Look at this rare footage of a polar bear on the hunt. Amazing.

\section{References}

http://science.sciencemag.org/content/363/6427/590

https://discourse.peacefulscience.org/t/_/4270/48

https://discourse.peacefulscience.org/t/_/4548

https://evolutionnews.org/2019/02/woo-hoo-in-science-review-ofdarwin-devolves-lenski-has-no-response-to-my-main-argument

https://evolutionnews.org/2019/02/train-wreck-of-a-review-aresponse-to-lenski-et-al-in-science

https://discourse.peacefulscience.org/t/_/4270/36

https://discourse.peacefulscience.org/t/_/4395

https://www.3quarksdaily.com/3quarksdaily/2019/02/darwin-doesdevolve-sometimes-so-what.html

https://discourse.peacefulscience.org/t/_/3964

https://discourse.peacefulscience.org/t/_/3267

http://apologetics-academy.org

http://themelios.thegospelcoalition.org/review/theistic-evolution-ascientific-philosophical-and-theological-critique-2

https://peacefulscience.org/articles/agree-behe/ http://science.sciencemag.org/content/316/5830/1427.full

https://en.wikipedia.org/wiki/Technobabble

https://evolutionnews.org/2018/09/critic-of-intelligent-designacknowledges-bad-design-arguments-dont-work

https://discourse.peacefulscience.org/t/_/4437 https://peacefulscience.org/articles/three-stories-on-adam/

https://discourse.peacefulscience.org/t/_/4658/27

https://discourse.peacefulscience.org/t/_/4271/29

https://discourse.peacefulscience.org/t/_/728

https://evolutionnews.org/2019/02/meetings-on-adam-and-eve-anew-approach-coming-to-a-church-near-you

https://telliamedrevisited.wordpress.com/2019/02/15/does-behesfirst-rule-really-show-that-evolutionary-biology-has-a-big-problem

https://telliamedrevisited.wordpress.com/2019/02/22/on-damagedgenes-and-polar-bears

https://discourse.peacefulscience.org/t/_/2199

https://telliamedrevisited.wordpress.com/2013/08/25/telliamedindian-philosopher-or-french-missionary

https://telliamedrevisited.wordpress.com/2019/02/18/reply-tomichael-behes-gentle-comment

https://discourse.peacefulscience.org/t/_/4530

https://peacefulscience.org/books/edge-evolution/

https://discourse.peacefulscience.org/t/_/4679

https://evolutionnews.org/2019/02/from-swamidass-on-chloroquineresistance-a-response-that-doesnt-respond

https://discourse.peacefulscience.org/t/_/4679/12 